УДК 616.34-007.272-036.1-085.281.9

\title{
Обгрунтування раціональної антибактеріальної терапії при гострій непрохідності кишечника (експериментальне дослідження)
}

\author{
T.I. Тамм, В.В. Непомнящий, Е.А. Шакалова, Д.П. Полянський, І.В. Івахно \\ proctology@med.edu.ua
}

Харківська медична академія післядипломної освіти, факультет загальної практики сімейної медицини, кафедра хірургії та проктології, м. Харків

\section{Реферат}

Вступ. Гостра кишкова непрохідність (ГКН) займає, за даними як вітчизняної, так і зарубіжної літератури, - 3-5 місце серед гострих хірургічних захворювань органів черевної порожнини. Багато авторів відзначають, що в післяопераційному періоді розвивається велика кількість ускладнень: нагноєння ран, неспроможність анастомозів, перитоніт, пієлонефрит, пневмонії.

Мета дослідження: вивчити ступінь накопичення антибактеріальних препаратів у стінці кишки вище місця перешкоди на моделі експериментального обтураційного ілеусу.

Матеріали та методи. Експеримент проведено на 28 лабораторних тваринах (щури), у яких сформована модель обтураційного ілеусу. Контрольну групу склали 4 тварини, у яких не проводили антибактеріальну терапію. У 8 тварин антибактеріальну терапію проводили метронідазолом, у 8 - цефтріаксоном і 8 - ципрофлоксацином. Тварин виводили з експерименту через 12, 24, 36 і 48 год. У ці терміни виконували забір двох біоптатів кишки, які розташовані на 1 см вище місця перешкоди. Перший фрагмент відправляли для гістологічного дослідження, другий - для визначення кількості антибактеріального препарату в стінці кишки методом високоефективної рідинної хроматографії (ВЕРХ).

Результати досліджень та їх обговорення. Згідно з хроматограмою, протягом доби відбувається кумуляція метронідазолу в стінці кишки вище місця перешкоди, досягаючи піку через 24 год експериментального обтураційного ілеусу, в подальшому концентрація метронідазолу в стінці кишки, незважаючи на продовження введення, знижується і до 36 год. на хроматограмі препарат не визначається. Вивчення кількості цефтріаксону і ципрофлоксацину в стінці кишки на моделі обтураційного ілеусу показало так само зниження здатності запаленої стінки до кумуляції цих препаратів у міру прогресування ілеусу. Слід зазначити, що в стінці запаленої кишки ці препарати знаходили навіть через 48 год в бактерицидних концентраціях. Встановлено, що через 12 год. існування обтураційного ілеусу у тварин, лікування яких здійснювали метронідазолом, стінка кишки була стоншена, і розміри $\dddot{11}$ не перевищували 0,5 мм. Через 24 год. зміни в порівнянні 3 попередніми були незначні: товщина стінки залишалася 0,5 мм. Значні мікроскопічні зміни виникли через 48 год. Істотно збільшився набряк стінки, що зумовило її потовщення до 1 мм. Зміни відповідали флегмоні кишкової стінки, що підтверджено лейкоцитарною інфільтрацією у всіх її шарах. Через 48 годин в стінці кишки тварин, які отримували ципрофлоксацин і цефтриаксон, деструктивні зміни виявлялися однотипно у вигл яді гнійного запалення.

Висновки. У міру прогресування гнійного запалення в стінці кишки при обтураційному ілеусі відбувається поступове зниження іiі здатності накопичувати цефтріаксон і ципрофлоксацин. Однак ці антибактеріальні препарати виявлені в бактерицидних концентраціях в стінці кишки через 48 год. Накопичення метронідазолу при обтураційному ілеусі в лікувальній концентрації відбувається в малозміненій стінці кишки протягом перших 24 годин і носить короткочасний характер, що підтверджено результатами експерименту.

Ключові слова: обтураційний ілеус, метронідазол, цефтріаксон, ципрофлоксацин, антибактеріальна терапія.

Reasoning of rational antibacterial therapy for acute bowel obstruction (experimental study)

T.I. Tamm, V.V. Nepomniashchyi E.A., Shakalova, D.P. Polianskyi, I.V. Ivakhno

Kharkiv Medical Academy of Postgraduate Education, Faculty of General Practice - Family Medicine, surgery and proctology chair, Kharkiv

Abstract

Introduction. Acute intestinal obstruction $(\mathrm{GCN})$ according to the data of both domestic and foreign literature is on the 3-5 place among acute surgical diseases of the abdominal organs. Many authors note that in the postoperative period a large number of complications develops: suppuration of wounds, failure of anastomoses, peritonitis, pyelonephritis, pneumonia.

Aim of the study: To study the degree of accumulation of antibacterial drugs in the intestinal wall above the obstacle on the model of experimental obstructive ileus.

Materials and methods. The experiment was conducted on 28 laboratory animals (rats) in which a model of obstructive ileus was formed. The control group consisted of 4 animals that did not have antibacterial therapy. In 8 animals, antibacterial therapy was performed with metronidazole; in 8 - ceftriaxone and 8 - ciprofloxacin. Animals were removed from the experiment after 12, 24, 36, and $48 \mathrm{~h}$. At this time, they performed abdominal bioptates, which were located $1 \mathrm{~cm}$ above the obstacle. The first fragment was sent for histological examination, the second 
for the determination of the amount of antibacterial drug in the intestinal wall by high performance liquid chromatography (HPLC).

Results of the study and their discussion. According to the chromatogram, metronidazole was accumulated in the intestinal wall above the obstruction site for 24 hours, reaching a peak after $24 \mathrm{~h}$ of experimental obstructive ileus, and subsequently, the metronidazole concentration in the intestinal wall continues to decrease up, and to $36 \mathrm{~h}$ on the chromatogram the drug is not determined. The study of the amount of ceftriaxone and ciprofloxacin in the intestinal wall in the model of obstructive ileus showed a similar decrease in the ability of the inflamed wall to cumulate these drugs as ileus progresses. It should be noted that in the wall of the inflamed gut, these drugs were found even after 48 hours in bactericidal concentrations. It is established that after 12 hours the existence of obstructive ileus in animals treated with metronidazole, the intestinal wall was thinned, and its size did not exceeded $0.5 \mathrm{~mm}$. After 24 hours. changes from the previous ones were slight: the wall thickness remained $0.5 \mathrm{~mm}$. Significant microscopic changes occurred after 48 hours. The swelling of the wall increased significantly, which caused it to thicken to $1 \mathrm{~mm}$. The changes corresponded to the phlegmon of the intestinal wall, which was confirmed by leukocyte infiltration in all its layers. After 48 hours in the intestinal wall of animals treated with ciprofloxacin and ceftriaxone, destructive changes were manifested in the same manner as purulent inflammation.

Conclusions. As the purulent inflammation progresses in the intestinal wall with obstructive ileus, there is a gradual decrease in its ability to accumulate ceftriaxone and ciprofloxacin. However, these antibacterial drugs were detected in bactericidal concentrations in the intestinal wall after $48 \mathrm{~h}$. The accumulation of metronidazole at obstructive ileus at therapeutic concentration occurs in the unmodified intestinal wall during the first 24 hours and is of short duration, which is confirmed by the results of the experiment.

Key words: obstructive ileus, metronidazole, ceftriaxone, ciprofloxacin, antibacterial therapy.

Вступ. Гостра кишкова непрохідність (ГКН) займає, за даними як вітчизняної, так і зарубіжної літератури, 3-5 місце серед гострих хірургічних захворювань органів черевної порожнини $[2-5,9]$. Багато авторів відзначають, що в післяопераційному періоді розвивається велика кількість ускладнень: нагноєння ран $(11,1-$ $77,8 \%)$, неспроможність анастомозів $(6,2-17,5 \%)$, перитоніт $(3,5 \%)$, пієлонефрит $(2,2 \%)$, пневмонії $(3,2 \%)[8,11]$. Як наслідок цього залишаються незадовільними результати лікування хворих 3 високими показниками післяопераційної летальності, яка досягає, за даними літератури, 4-32\% $[6,10]$. Такий діапазон післяопераційної летальності пов'язаний з особливістю даної патології.

Так, за даними статистики, в 80\% випадків ГКН буває непухлинної етіології і летальність в цій групі хворих не перевищує $(2,6-15,9 \%)$ [5, 9] При пухлинах товстої кишки, які ускладнюються обтураційним ілеусом, у 42-85\% випадків післяопераційна летальність досягає 40\% [4]. Такі цифри обумовлені двома причинами: обтураційний ілеус - повільно розвивається з невираженою клінікою і в зв'язку з цим хворі поступають в стаціонар пізніше 2-3 доби [1]; крім того ці хворі представлені старшими віковими групами та страждають на одне, а частіше i більше, хронічних захворювань $[2,5,8]$.

У даний час в невідкладної хірургії існує кілька варіантів профілактики гнійно-септичних ускладнень. Ще в 1941 p. W.O. Abbot запропонував інтубацію кишечника з евакуацією вмісту 3 просвіту кишки. Крім цього запропоновані: субопераційний лаваж кишечника $[7,8]$, череззондове введення антибактеріальних препаратів [10]. Усі вищевказані способи профілактики гнійно-септичних ускладнень недосконалі, тому що не знижують число гнійно-септичних ускладнень [8].
Мета дослідження: вивчити ступінь накопичення антибактеріальних препаратів у стінці кишки вище місця перешкоди на моделі експериментального обтураційного ілеусу.

Матеріали та методи. Експеримент проведено на 28 лабораторних тваринах (щури), у яких сформована модель обтураційного ілеусу. Контрольну групу склали 4 тварини, у яких не проводили антибактеріальну терапію. У 8 тварин антибактеріальну терапію проводили метронідазолом; у 8 - цефтріаксоном і 8 - антибактеріальну терапію проводили ципрофлоксацином. Кількість антибактеріальних препаратів вводили у дозі з перерахунком на масу тіла тварини, а шлях і кратність введення здійснювали згідно з інструкцією. Тварин виводили з експерименту через $12,24,36$ і 48 год. У ці терміни виконували забір двох біоптатів кишки, розташованих на 1 см вище місця перешкоди. Перший фрагмент відправляли для гістологічного дослідження, другий - для визначення кількості антибактеріального препарату в стінці кишки методом високоефективної рідинної хроматографії (BEPX).

Результати досліджень та їх обговорення. Визначення концентрації метронідазолу здійснювали за даними хроматограм (рис. 1-3).

Згідно $з$ хроматограмами, протягом доби відбувається кумуляція метронідазолу в стінці кишки вище місця перешкоди, досягаючи піку через 24 год існування експериментального обтураційного ілеусу в кількості 2,715 мкг / г запаленої тканини. В подальшому концентрація метронідазолу в стінці кишки, незважаючи на продовження введення, знижується і до 36 год. на хроматограмі (рис. 3) препарат не визначається. Дані хроматограм у кількісному вираженні представлені в таблиці 1. 
==== Shimadzu LCsolution Analysis Report ====

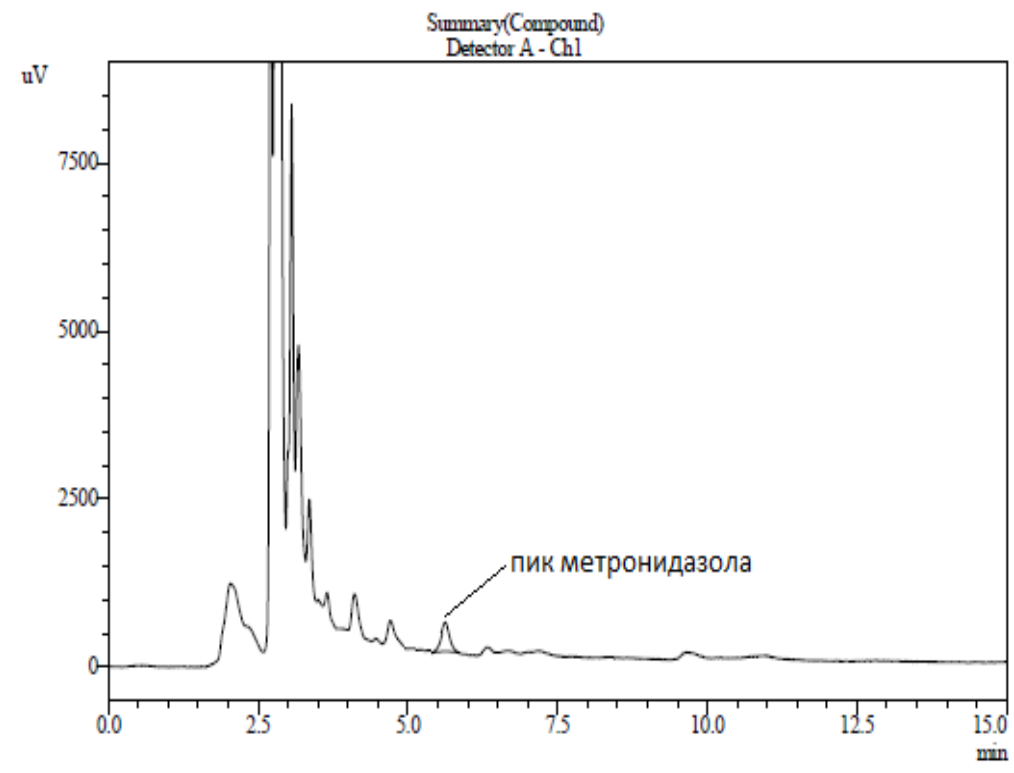

<< Detector A >

ID $=1$ Coupound Name: Metronidazole

\begin{tabular}{|l|r|r|r|r|r|}
\hline \multicolumn{1}{|c|}{ Title } & \multicolumn{1}{|c|}{ Ret. Time } & \multicolumn{1}{c|}{ Area } & Taling Factor & Resolution & |heoretical Plate: \\
\hline 1 12__12.lcd & 5.621 & 4237 & 0.000 & 0.000 & 6209.392 \\
\hline Average & 5.621 & 4237 & 0.000 & 0.000 & 6209.392 \\
\hline$\%$ RSD & 0.000 & 0.000 & 0.000 & 0.000 & 0.000 \\
\hline
\end{tabular}

Рис. 1. Хроматограма розчину, отримана з проби через 12 год. експериментального ілеусу. ==== Shimadzu LCsolution Analysis Report ====

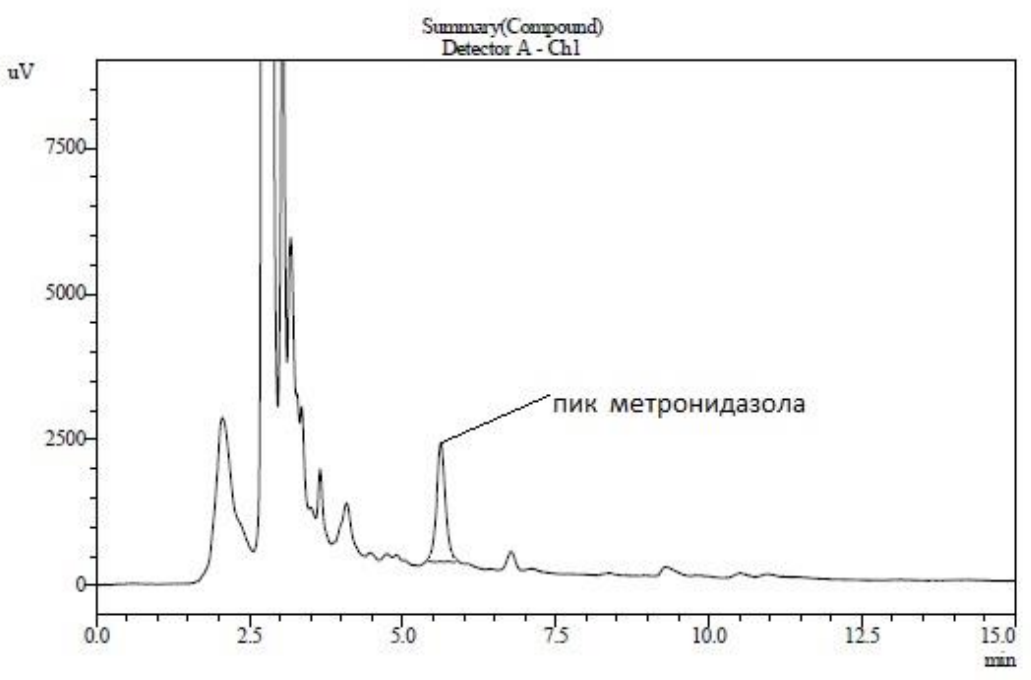

$\ll$ Detector $\mathrm{A} \gg>$

ID $=1$ Coumpound Name: Metronidazole

ID $=1$ Compound Name: Metronudzzole
\begin{tabular}{|l|r|r|r|r|r|}
\hline Title & Ret. Time & Area & Taling Factor & Resolution & heoretical Plater \\
\hline 1.24 13.lcd & 5.617 & 19650 & 0.000 & 0.000 & 6646.864 \\
\hline Average & 5.617 & 19650 & 0.000 & 0.000 & 6646.864 \\
\hline$\%$ RSD & 0.000 & 0.000 & 0.000 & 0.000 & 0.000 \\
\hline
\end{tabular}

Рис. 2. Хроматограма розчину, отримана 3 проби через 24 год. експериментального ілеусу. 


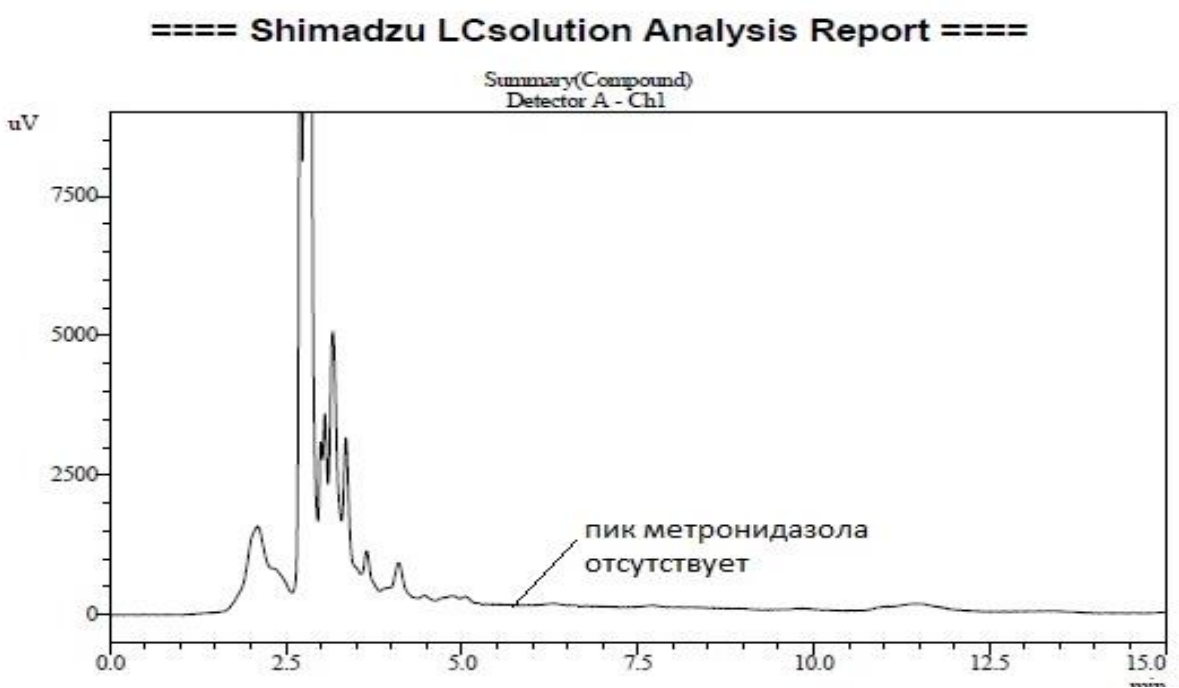

Рис. 3. Хроматограма розчину, отримана з проби через 36 год. експериментального ілеусу: відсутність метронідазолу в розчині.

Таблиця 1

Концентрація метронідазолу в тканинах кишки при обтураційному ілеусі

\begin{tabular}{|l|l|l|l|l|l|}
\hline \multicolumn{1}{|c|}{ Зразок } & $\begin{array}{c}\text { Площа піку } \\
\text { метронідазолу }\end{array}$ & $\begin{array}{c}\text { Маса } \\
\text { тканини, г }\end{array}$ & $\begin{array}{c}\text { Об’єм розчи- } \\
\text { ну, мл }\end{array}$ & $\begin{array}{c}\text { Концентрація, } \\
\text { мкг/мл }\end{array}$ & $\begin{array}{c}\text { Концентрація, } \\
\text { мкг/г }\end{array}$ \\
\hline Контроль & - & 1,61 & 7,0 & - & - \\
\hline 12 год & 4237 & 1,46 & 7,0 & 0,119 & 0,570 \\
\hline 24 год & 19650 & 1,42 & 7,0 & 0,551 & 2,714 \\
\hline 36 год & - & 1,64 & 7,0 & - & - \\
\hline $\begin{array}{l}\text { Розчин } \\
\text { порівняння }\end{array}$ & 4014 & - & - & 0,11248 & - \\
\hline
\end{tabular}

Вивчення кількості цефтріаксона і ципрофлоксацина в стінці кишки на моделі обтураційного ілеусу показало так само зниження здатності запаленої стінки до кумуляції цих пре- паратів у міру прогресування ілеусу. Динаміка зниження кількості цих антибактеріальних препаратів у тканинах представлена на рисунку 4.

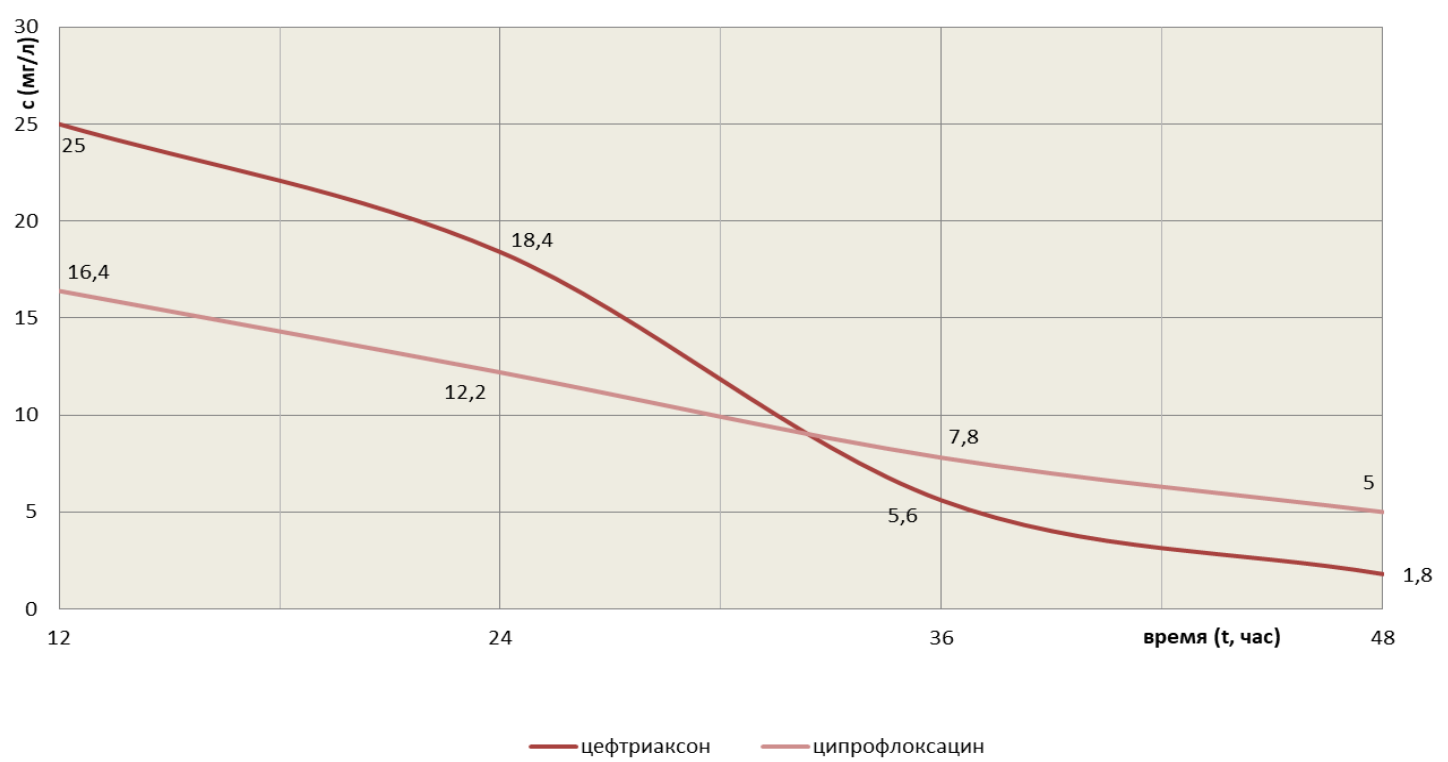

Рис. 4. Динаміка антибактеріальних препаратів у тканинах при обтураційному ілеусі. 
Слід зазначити, що в стінці запаленої кишки ці препарати знаходили навіть через 48 год. у бактерицидних концентраціях.

Другий фрагмент стінки кишки віддавали на гістологічне дослідження для визначення динаміки морфологічного процесу під впливом перерахованих антибактеріальних препаратів.

Встановлено, що через 12 год. існування обтураційного ілеусу у тварин, лікування яких здійснювали метронідазолом, стінка кишки була стоншена, і розміри пї не перевищували 0,5 мм. Товщина слизової оболонки - 0,2-0,42 мм; під- слизовий шар був ледь помітний, а товщина м'язового шару була 0,07-0,13 мм. Відзначена десквамація ентероцитів із поверхні ворсинок і оголення власної пластинки слизової оболонки. Це відповідало гострій запальній реакції з набряком слизової і розширенням судин мікроциркуляції. Виявлено присутність поліморфноядерних клітин, лейкоцитів і плазматичних клітин. Імунокомпетентні клітини виявлені в судинах підслизового шару. М'язовий шар кишкової стінки витончений, але без вагомих патологічних змін (рис. 5).

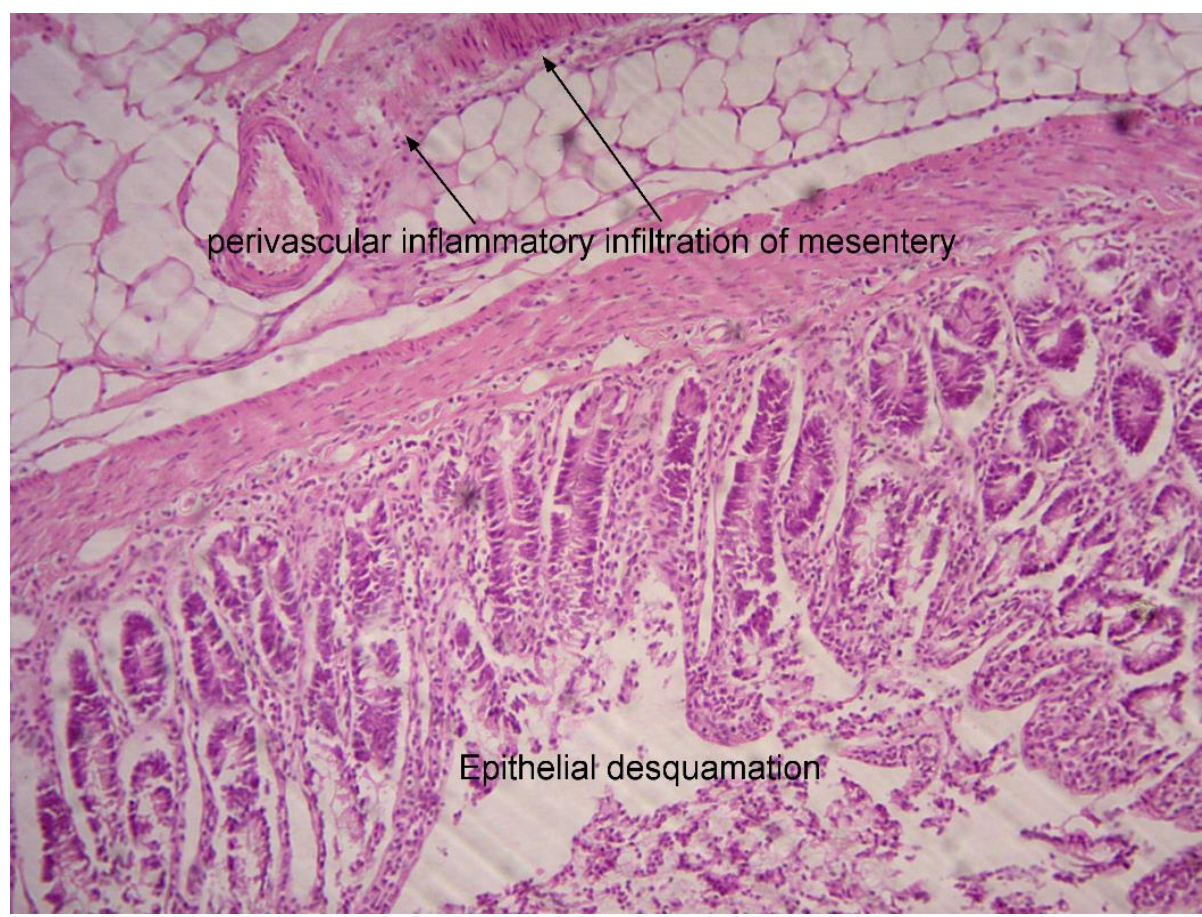

Рис. 5. Гістограма тонкої кишки (12 год.): десквамація ентероцитів поверхні ворсинок з оголенням власної пластинки слизової. Зб. × 100. Г + Е.

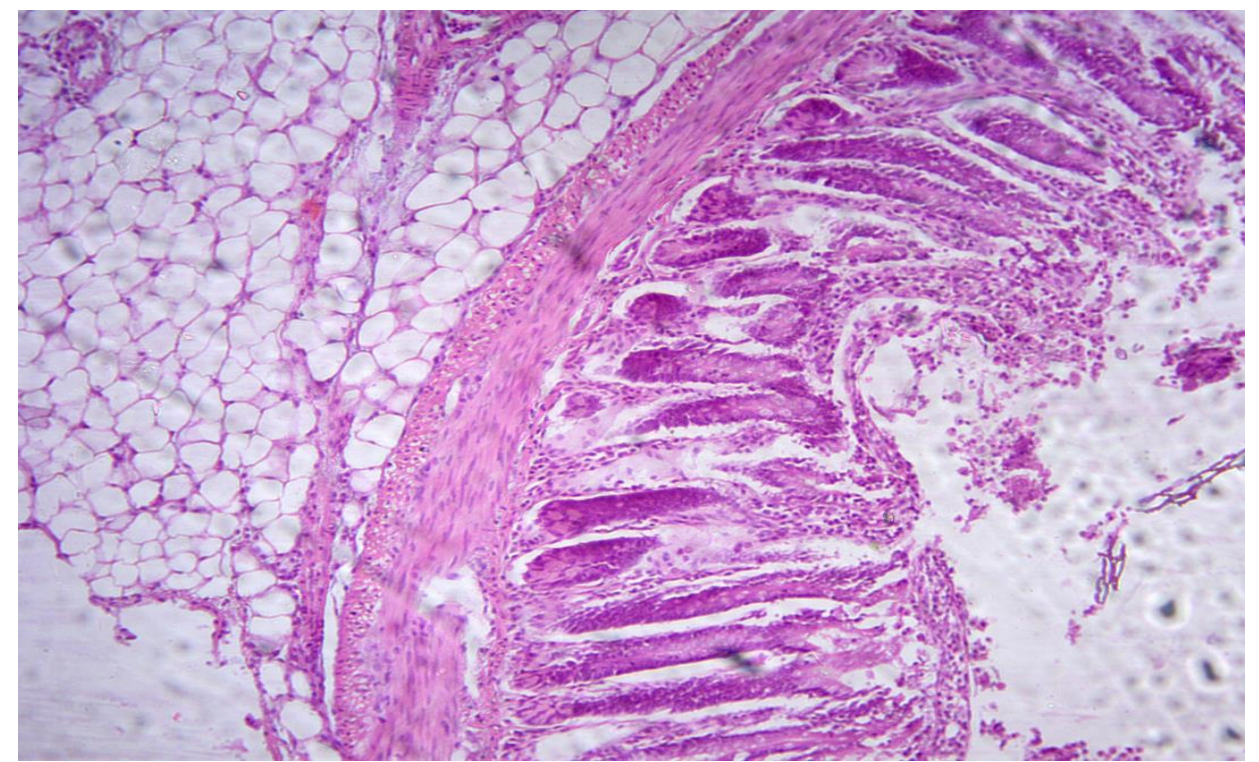

Рис. 6. Гістограма стінки кишки (24 год.): виражена десквамація епітелію слизової оболонки. Запальна реакція представлена нейтрофілами і макрофагами. 3б. ×100. Г + Е. 
Через 24 год. зміни порівняно 3 попередніми були незначні: товщина стінки залишалася 0,5 мм. Зберігалися явища десквамації епітелію слизової оболонки. Виразність запальної реакції без суттєвої динаміки. У клітинному складі периваскулярних інфільтратів переважали плазматичні клітини, нейтрофільні лейкоцити і макрофаги (рис. 6).

Значні мікроскопічні зміни виникли через 48 год. Істотно збільшився набряк стінки, що зумовило її потовщення до 1 мм. При цьому м'язовий шар був значно витончений, а потовщення стінки визначалося переважно черезвиражений набряк підслизового шару. Ці зміни відповідали флегмоні кишкової стінки, що підтверджено лейкоцитарною інфільтрацією у всіх їі шарах (рис. 7).

У групах тварин, які отримували цефтріаксон і ципрофлоксацин через 24 год. при гістологічному дослідженні виявлено, що мікрофлора масивно інфільтрувала слизову оболонку без інвазії в нижчележачі шари.

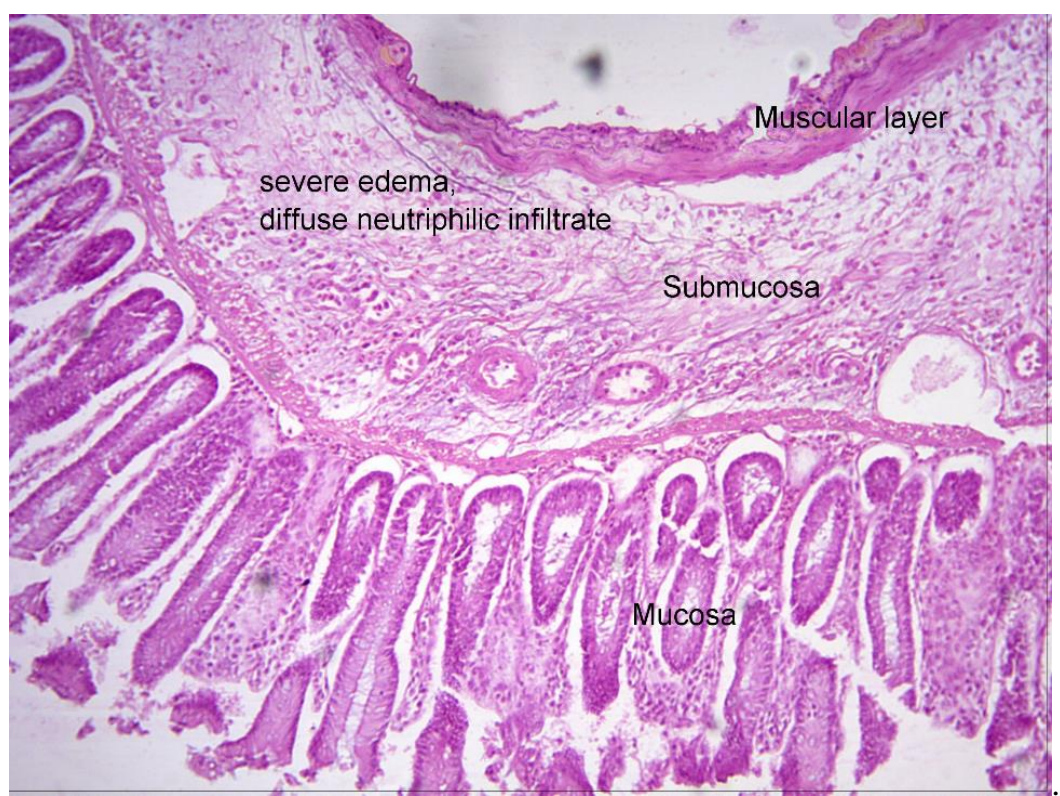

Рис. 7. Гістограма стінки кишки (36 год.): лейкоцитарна інфільтрація всіх шарів стінки і виражений набряк (3б. х 100. Г + E).

Якісний склад клітин характеризувався наявністю в однаковій кількості лімфоцитів і сегментоядерних лейкоцитів, але лейкоцити в ці терміни існування обтураційного ілеусу не проникають в епітеліальний покрив ворсинок (рис. 8).

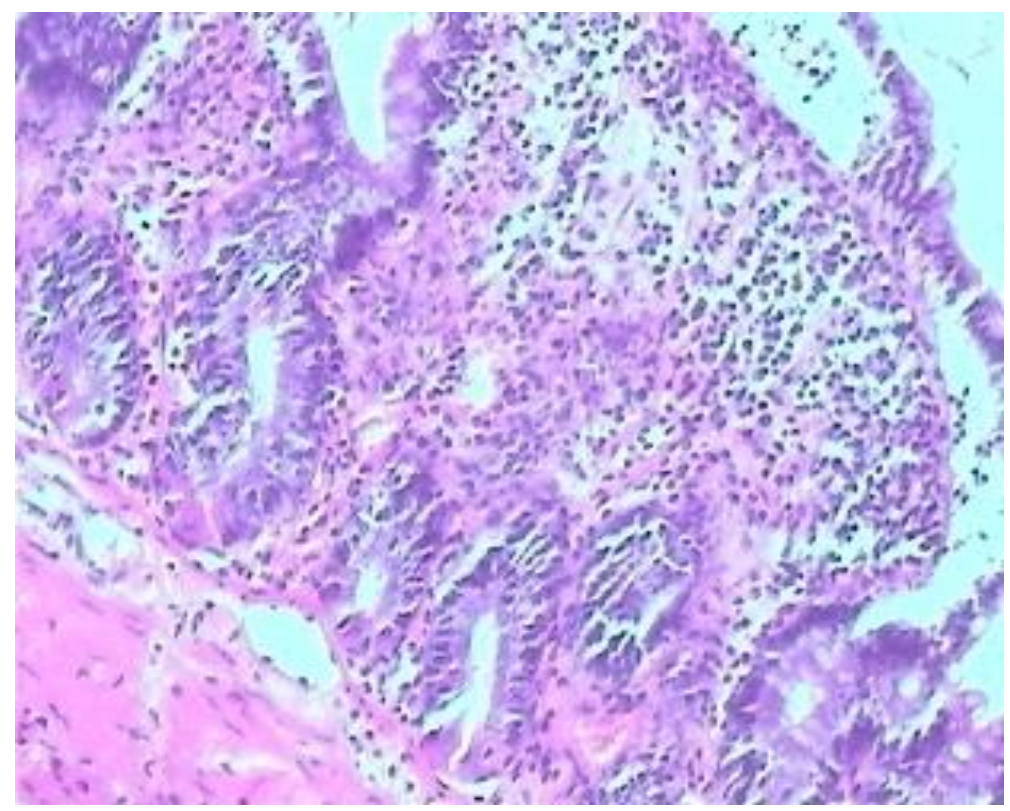

Рис. 8. Гістоструктура стінки кишки у тварини через 24 год.: рівне співвідношення нейтрофілів і лімфоцитів у запальному інфільтраті слизової оболонки. Забарвлення Г + Е. 3б. × 200. 
Через 48 годин у стінці кишки тварин, які отримували ципрофлоксацин і цефтріаксон, деструктивні зміни виявлялися однотипно у вигляді гнійного запалення: слизова оболонка поз- бавлена епітеліального вистилання, тотальна десквамація ворсинок, строма колабована і на поверхні слизової оболонки велика кількість бактерій (рис. 9).

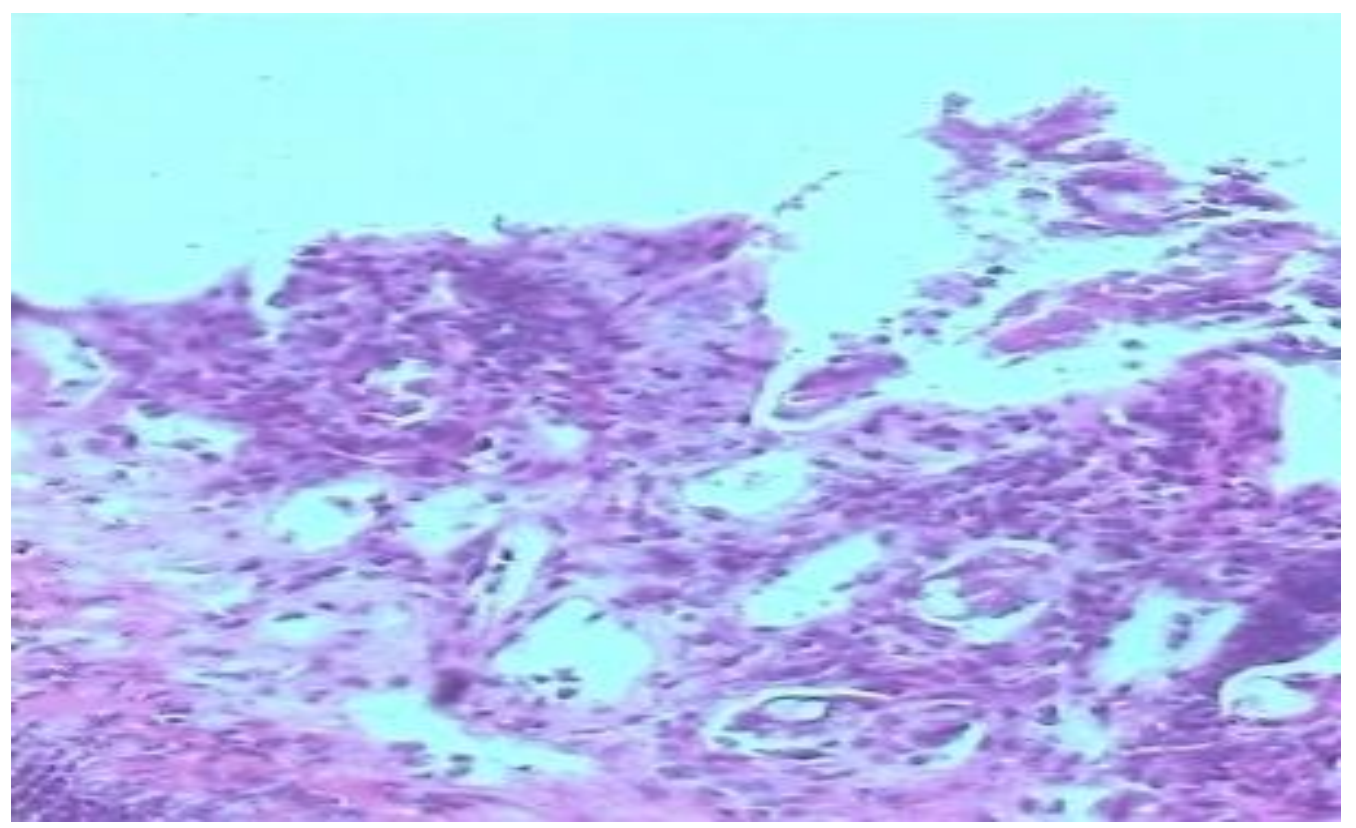

Рис. 9. Гістоструктура слизової оболонки кишки на моделі обтураційного ілеусу (48 год.): виявлена ерозія слизової оболонки з наявністю колоній бактерій. Забарвлення Г + Е. 3б. × 200.

Таким чином, на моделі експериментального обтураційного ілеусу було встановлено, що в привідній кишці вище місця перешкоди в силу закономірності процесів розвивається гнійне запалення, яке $\epsilon$ джерелом багатьох гнійно-септичних ускладнень у післяопераційному періоді. На моделі експериментального ілеусу встановлено, що флегмонозно змінена стінка кишки здатна на короткий час накопичувати і утримувати метронідазол, який уповільнює процес розвитку гнійного запалення. Триваліше в стінці кишки знаходяться ципрофлоксацин і цефтріаксон, що стримують процеси деструкції на тлі прогресуючого запалення.
Висновки. 1. У міру прогресування гнійного запалення в стінці кишки при обтураційному ілеусі відбувається поступове зниження їі здатності накопичувати цефтріаксон і ципрофлоксацин. Однак ці антибактеріальні препарати виявлені в бактерицидних концентраціях у стінці кишки через 48 год.

2. Накопичення метронідазолу при обтураційному ілеусі в лікувальній концентрації відбувається в малозміненій стінці кишки протягом перших 24 годин і має короткочасний характер, що підтверджено результатами експерименту.

Інформація про конфлікт інтересів. Автори заявляють про відсутність конфлікту інтересів при виконанні наукового дослідження та підготовці даної статті.

Інформація про фінансування. Автори гарантують, що вони не отримували жодних винагород у будь-якій формі, здатних вплинути на результати роботи.

Особистий внесок кожного автора у виконання роботи:

Tамм T.I. - ідея та контроль дослідження.

Непомнящий В.В. - розпрацювання мети, набір матеріалу.

Шакалова Е.А. - огляд літератури.

Полянський Д.П. - проведення експерименту на тваринах.

Івахно I.B. - оформлення дизайну статті згідно з вимогами.

\section{Список використаної літератури}

1. Aliev S.A. Osobennosti diagnostiki i hirurgicheskoj taktiki pri spaechnoj kishechnoj neprohodimosti. Hirurgija. 2005; 2:13-17. [In Russian].

2. Benedykt V. V. Patohenetychni aspekty porushen rukhovoi funktsii tonkoi kyshky u khvorykh na hostru neprokhidnist kyshky ta yikh korektsiiu. Nauk. visn. Uzhhorod. un-tu. Seriia: Medytsyna. 2015; 1:48-52. [In Ukrainian]. 
3. Benedykt V. V. Intubatsiia tonkoi kyshky. Spirni pytannia i mozhlyvi shliakhy yikh vyrishennia. Khark. khirurh. Shkola. 2014; 2:51-56. [In Ukrainian].

4. Benedykt V. V. Kliniko-patohenetychne obhruntuvannia likuvalnoi taktyky na etapakh khirurhichnoho likuvannia khvorykh na hostru neprokhidnist tonkoi kyshky (kliniko-eksperymentalne doslidzhennia). [avtoreferat dysertatsii]. Ternopil. 2017; 43p.

5. Bojko V.V., Timchenko N.V., Bojchuk I.P., Beljavskij A.V.. Faktori riska vozniknovenija posleoperacionnogo parezu kishechnika u pacientov, operirovannyh na tolstoj kishke. Harkyvs 'ka hyrurgychna shkola. 2014; 2:47-51. [In Russian].

6. Lurin I.A., Titomir I.A., Hladyshchenko O.I. et al. Pryntsypy nadannia khirurhichnoi dopomohy khvorym na hostru spaikovu neprokhidnist. Khark. khirurh. shkola. 2013; 4:114-116. [In Ukrainian].

7. Radzihovskij A.P., Beljaeva O.A., Kolesnikov E.B. et al. editors. Neprohodimost' kishechnika: rukovodstvo dlja vrachej. Kyiv: Feniks; 2012. 504 p. [In Russian].

8. Bohun O.A. Profilaktyka hniino-septychnykh uskladnen u khvorykh na hostru neprokhidnist kyshechnyku [avtoreferat dysertatsii]. Kharkiv; 2010. 24 p. [In Ukrainian].

9. Ermolov A.S., Jarcev P.A., Lebedev A.G. et al. editors. Diagnostika i lechenie ostryh hirurgicheskih zabolevanij organov brjushnoj polosti. Opyt moskovoskogo zdravohranenija 1992-2014 gg. Moskva: Izd. dom Vidar; 2015. 640 p. [In Russian].

10. Shaprynskyi V.O., Kaminskyi O.A. et al. Kompleksne likuvannia hostroi kyshkovoi neprokhidnosti ne pukhlynnoho henezu. Khark. khirurh. shkola. 2014; 2:62-65. [In Ukrainian].

11. Todurov I.M., Beljanskij L.S., Manojlo N.V., Perehrestenko A.V. Sovremennye principy i vozmozhnosti hirurgicheskogo lechenija bol'nyh ostroj neprohodimost'ju tolstoj kishki. Aktual'ni pytannja nevidkladnoi hirurgii. 2008; 2:290-295. [In Russian].

12. European Pharmacopoeia (Ph. Eur.) 9th Edition (EP 9.0, 2017).

13. Kovalenko V.N. editor. Spravochnik "Kompendium 2013 - lekarstvennye preparaty". Kyiv: Morion; 2013. 2360 p. [In Russian].

Стаття надійшла до редакції: 28.10.2019 р. 